\title{
APRIORI ALGORITHM IMPLEMENTATION TO DETERMINE PURCHASE PATTERNS OF RAW MATERIALS AT PT PENJALINDO NUSANTARA
}

\author{
Dedi Rozaq Prastyo; Sri Dianing Asri2* \\ Informatics Study Program ${ }^{1,2}$ \\ Universitas Mercu Buana \\ www.mercubuana.ac.id \\ 41516320005@mercubuana.ac.id 1; dianing.asri@mercubuana.ac.id 2* \\ ${ }^{*}$ ) Corresponding Author
}

\begin{abstract}
PT. Penjalindo Nusantara is a manufacturing company in the packaging field where production depends on customer demand or what is commonly known as job orders so that timely production work and availability of sufficient materials are mandatory for the company. There was a problem in the implementation of the raw material supply strategy by PT. Penjalindo Nusantara caused delays in the supply of raw material stocks. The solution to this problem is to apply the Apriori algorithm to find out what raw materials are being purchased simultaneously so that it can be the basis for implementing a purchasing strategy in supporting the effectiveness of procurement of raw material stocks and also saving time in sending raw materials by suppliers. This research uses a Web-based data mining application to find the raw material purchase pattern. The result of this research is obtained 11 patterns of purchasing raw materials using a minimum value of $90 \%$ support and a minimum of $100 \%$ confidence with a lift ratio of 1 as a reference for determining which raw materials will be purchased at the same time.
\end{abstract}

Keywords: Data Mining, Apriori Algorithm, Raw Materials, Web-Based.

\begin{abstract}
Abstrak- PT. Penjalindo Nusantara adalah suatu perusahaan yang bergerak di bidang manufaktur kemasan yang di mana produksi bergantung pada permintaan pelanggan atau yang biasa disebut job order, sehingga pengerjaan produksi yang tepat waktu dan ketersedian material yang mencukupi menjadi hal yang wajib dilakukan oleh perusahaan. Terjadi permasalahan dalam penerapan strategi persediaan bahan baku oleh PT. Penjalindo Nusantara yang tidak efektif menyebabkan terjadi keterlambatan dalam penyedian stok material produksi. Solusi dari masalah ini adalah dengan melakukan penerapan algoritma Apriori untuk mengetahui material produksi apa saja yang dibeli secara bersamaan sehingga dapat menjadi dasar untuk menerapkan strategi pembelian dalam menunjang efektivitas pengadaan stok material produksi dan juga menghemat waktu pengiriman material produksi oleh supplier. Penelitian ini menggunakan aplikasi data mining berbasis Web-based untuk menemukan pola pembelian bahan baku. Hasil dari penelitian ini mendapatkan 11 pola pembelian material produksi dengan menggunakan nilai minimum support 90\% dan minimum confidence 100\% dengan lift ratio 1 sebagai acuan untuk menentukan material produksi mana saja yang akan dibeli pada waktu bersamaan.
\end{abstract}

Kata Kunci: Data Mining, Algoritma Apriori, Bahan Baku, Web-Based.

\section{INTRODUCTION}

To make the raw material inventory management and inventory cost more efficient, controlling the raw material purchases according to the production plan so that there are no shortages and excesses in the raw material inventory[1]. The Supply Chain department oversees the raw materials purchase planning and controlling the company materials including providing raw materials, controlling the amount of inventory, as well as a system for storing and managing goods in and out of the warehouse.
Controlling the amount of inventory is one of the most important factors in optimizing inventory. Inventory Control is an activity in managing inventory to suit the needs and maintain the raw material stability. PT. Penjalindo Nusantara is a manufacturing company in the packaging field where production depends on customer demand[2], there is a problem with the effectiveness of raw material stock control[3] and delays in ordering raw materials because the company does not have the right raw material order scheduling[4][5] caused the problem for the production activity. So far, the company has 
overcome the problem if there is no stock for the raw material that is needed in production by using existing materials with the same specifications according to product needs, but it cost a lot of production cost[5].

To fix problems in the material procurement planning, the solution is to determine which raw materials will be purchased at the same time, the basis of determining the raw material purchased at the same time is to analyze what raw material is often purchased at the same time for 11 months using data mining. One of the algorithms that belong to an association in data mining that matches is the Apriori algorithm. Apriori algorithm aims to find frequent itemsets in a set of data. Apriori algorithm defined a process to find Apriori rules that meet minimum requirements for support and minimum requirements for confidence.[6]

This research seeks to analyze the purchase of raw materials in 11 months by using the Apriori algorithm and obtained the association rules. So, the results can be identified by seeing which raw materials are often purchased simultaneously for over 11 months.

\section{Literature Research}

There is some literature research related to Apriori Algorithm. Munarwan et al [7]. This research discusses the Market Basket Analysis method works by using the Apriori Algorithm to determine the purchase patterns in one transaction. The results obtained the average minimum support by 0,1563 and minimum confidence by 0,3486 , and the highest support with value by 0,3125 and the highest confidence by 0,7143 contains 3 itemsets that if buy AM and Buy SN Then Buy RT. Another research in 2018 D. S. Wijaya et al[8] aims to analyze the data to determine the correlation between fish catch that may affect another fish, this research using the Association Rules method and obtained the value of highest minimum support by $50 \%$ and the highest minimum confidence by $80 \%$, the result is if getting Yellowfin Tuna is also getting the Bigeye Tuna. And then in 2020, Y. Nawawi et al[9] presents a study to find the relation of the book borrowed at the same time by using the Association Rule. The results obtained 50 association rules with the highest rule is lending of communication science and psychology book with support and confidence of $8.17 \%$. And then the research related to maintaining the item stock is done by Junaidi[10] in 2019, The goal of this research is to determine the inventory of goods by analyzing which items are sold simultaneously using the Ariori algorithm, the process is getting the results by setting the minimum support $60 \%$ and the minimum confidence by $90 \%$, the results are obtained 24 associative rules with the minimum support $60 \%$ and the minimum confidence $90 \%$ that contains the items which items are sold simultaneously and can be used as a reference for providing stock of items. And then the research in 2018 by D. A. O. Turang et al [11], this research analysed the inventory stock system and implementing the system using the Differential Evolution Algorithm, this research analyzed the inventory data and sales data, sales and inventory data are calculated to determine the estimated safety stock and reorder point so that the status of the raw material inventory position can be determined. Lot sizing method is successfully used to calculate the number of orders and the period of ordering in order to achieve optimal costs and achieve efficiency of the company.

The GAP analysis from the above research with this research is using the Apriori algorithm to determine the raw material purchasing pattern which can be used as a reference for determining the supply of raw material stocks to be more effective and reduce production costs because the required raw materials are always on stock and there is no need to use other raw materials which can burden production costs.

\section{MATERIALS AND METHODS}

The analysis is an attempt to observe in detail a thing or object by describing its constituent or constituent components for further research[12]. In collecting data, it is necessary to carry out certain methods to obtain data that suits your needs. The method used in this research is to make a direct observation of the work process by conducting interviews with several users to obtain the required data and then recording the data systematically based on the facts in PT. Penjalindo Nusantara, study the literature to collect references from books, articles, papers, journals about the apriori algorithm[13]. Association analysis or association rule mining is a data mining technique to find associative rules between a combination of items[14]. Association rule is a method that aims to find patterns that often appear among many transactions, where each transaction consists of several items. One of the stages in this method is called high-frequency pattern analysis. The importance of an associative rule can be determined by two parameters, namely support and confidence[15]. Support is the percentage of the combination of these items in the database, while confidence (certainty value) is the strong relationship between items in the association rule.[16] 
The basic methodology of association analysis is divided into two stages:

\section{Analyze the high-frequency pattern.}

This stage looks for a combination of items that meet the minimum requirements of the support value in the database. The value of an item's support is obtained by the formula:[17]

Support $(A)=\frac{\sum \text { Transactions contains } A}{\sum \text { Transactions }} \times 100 \%$

While the support value of 2 items is obtained from the following formula:

Support $(A, B)=\frac{\sum \text { Transactions contains } A, B}{\sum \text { Transactions }} \times 100 \%$

And then to find the combination of 3 items, the support value of 3 items is obtained from the following formula:

Support $(A, B, C)=$

$\frac{\sum \text { Transactions contains } A, B, C}{\sum \text { Transactions }} \times 100 \%$

\section{The determination of association rules}

After all high frequent itemset patterns are found, then the associative rules that meet the minimum requirements for the confidence by calculating the confidence of associative rules $\mathrm{A} \rightarrow$ $\mathrm{B}$ can be obtained from the following formula:

Confidence $(B \mid A)=$

$\frac{\sum \text { Transactions Contains } A, B}{\sum \text { Transactions } A} \times 100 \%$

\section{Research Stages}

The author using the systematic research steps that contain an outline of this research to help the research flow to be well directed. The steps that the author implemented can be seen below:[18]

1. Preliminary Study

The preliminary study includes a literature study related to the research topic. This step is to search the problem and study the problem that exists in the PT Penjalindo Nusantara, and then decide the background of the problem, scope of the problem, and then search some literature that related to the problem and implementing the solutions that suitable for the problems.

2. Collecting the Data

Collect the data by conducting some interviews with users related to the process that has a problem. This step is to aim the data that contains information of raw material purchase history data that purchased in January 2020 to November 2020, the data collected will be cleaned first to streamline the next process.

\section{Data Mining Implementation}

After collecting the data, the next process is identifying the type of raw material that want to be processed with the data mining, in this research, the raw material type that will be used is raw material ink, and then the next step is to determine the data mining method, in this research the data mining method is using the apriori algorithm to find the purchase pattern of raw material.

4. Processing the Data

After the data is ready to process with the apriori algorithm. The next process to processing the data by using a web-based application that has a function to analyze the data with the apriori algorithm, this application is running with PHP programming languages and using MySQL for the database. This application will import the data that will be processed with the .csv extension.

5. Analyze the Results

Analysis of the results by determining the final association rules done by calculating the data with the application.

6. Conclusions

The results of the purchase patterns calculation using the apriori algorithm is creating the percentages of raw material ink purchase patterns and showing the final results for the support value percentages and the confidence value percentages.

\section{RESULTS AND DISCUSSION}

In the process of analysis, several criteria are needed to be used in the implementation of data mining. In this research, the author collects the data with the appropriate criteria and attributes from the purchase transaction. The attributes used are the total purchase transactions and the type of material purchased and then processing the data with the apriori algorithm.

\section{List of Raw Materials Types}

The data of raw material ink with the item iddata that obtained for the data mining process using the apriori algorithm method can be seen in Table 1 below:

Table 1. List of Materials Type of PT Penjalindo Nusantara

\begin{tabular}{ccl}
\hline No & Item ID & \multicolumn{1}{c}{ Description } \\
\hline 1 & RMI0000178 & PU_SRKF 0001 MEDIUM UF T3_CT \\
\hline 2 & RMI0000187 & PU_VYS WHITE UN @15 KG_HII \\
\hline 3 & RMI0000498 & PU_LAMIC F 739 BLUE @180 KG_HII \\
\hline 4 & RMI0000478 & PU_LAMIC F 716 RED @180 KG_HII \\
\hline 5 & RMI0000481 & PU_LAMIC F 950 ORANGE @180 KG_HII \\
\hline 6 & RMI0000487 & PP_LNA 723 YELLOW @180 KG_HII \\
\hline 7 & RMI0000488 & PP_LNA 739 BLUE @180 KG_HII \\
\hline 8 & RMI0000525 & PP_LNA 795 BLACK @15 KG (PJ)_HII
\end{tabular}


VOL. 6. NO. 2 FEBRUARY 2020

P-ISSN: 2685-8223 I E-ISSN: 2527-4864

DOI: 10.33480 /jitk.v6i2.1909
JITK (JURNAL ILMU PENGETAHUAN DAN TEKNOLOGI KOMPUTER)

\begin{tabular}{ccl}
\hline No & Item ID & \multicolumn{1}{c}{ Description } \\
\hline 9 & RMI0000484 & PU_LAMIC F MEDIUM @180 KG_HII \\
\hline 10 & RMI0000476 & PU_LAMIC F 702 RED @180 KG_HII \\
\hline 11 & RMI0000485 & $\begin{array}{l}\text { PU_LAMIC F 722 TR YELLOW @180 } \\
\text { KG_HII }\end{array}$ \\
\hline 12 & RMI0000491 & PP_LNA 702 RED @180 KG_HII \\
\hline 13 & RMI0000086 & PU_LAMIC F 779 GREEN_HII \\
\hline 14 & RMI0000526 & PP_LNA 817 RED @180 KG_HII \\
\hline
\end{tabular}

Source: [19]

\section{Raw Material Ink Purchase Pattern}

The data of raw material ink from the January 2020 - November 2020 period can be seen in Table 2 below:

Table 2. Raw Material Ink Purchase Pattern

\begin{tabular}{|c|c|}
\hline Month & Description \\
\hline January & $\begin{array}{l}\text { RMI0000178, RMI0000187, RMI0000498, } \\
\text { RMI0000478, RMI0000481, RMI0000487, } \\
\text { RMI0000488, RMI0000525, RMI0000484, } \\
\text { RMI0000476, RMI0000485, RMI0000491 }\end{array}$ \\
\hline February & $\begin{array}{l}\text { RMI0000484, RMI0000498, RMI0000478, } \\
\text { RMI0000481, RMI0000485, RMI0000086, } \\
\text { RMI0000488, RMI0000525, RMI0000187, } \\
\text { RMI0000476, RMI0000526, RMI0000491, } \\
\text { RMI0000487, RMI0000178 }\end{array}$ \\
\hline March & $\begin{array}{l}\text { RMI0000498, RMI0000476, RMI0000478, } \\
\text { RMI0000481, RMI0000488, RMI0000487, } \\
\text { RMI0000525, RMI0000187, RMI0000484, } \\
\text { RMI0000485, RMI0000086, RMI0000526, } \\
\text { RMI0000491, RMI0000178 }\end{array}$ \\
\hline April & $\begin{array}{l}\text { RMI0000484, RMI0000498, RMI0000485 } \\
\text { RMI0000478, RMI0000525, RMI0000476 } \\
\text { RMI0000481, RMI0000488, RMI0000487 } \\
\text { RMI0000491, RMI0000086 }\end{array}$ \\
\hline May & $\begin{array}{l}\text { RMI0000484, RMI0000498, RMI0000478, } \\
\text { RMI0000485, RMI0000481, RMI0000086, } \\
\text { RMI0000487, RMI0000525, RMI000047,, } \\
\text { RMI0000488, RMI0000491, RMI0000526 }\end{array}$ \\
\hline June & $\begin{array}{l}\text { RMI0000498, RMI0000476, RMI0000478, } \\
\text { RMI0000485, RMI0000484, RMI0000487, } \\
\text { RMI0000481, RMI0000488, RMI0000491, } \\
\text { RMI0000525 }\end{array}$ \\
\hline July & $\begin{array}{l}\text { RMI0000484, RMI0000478, RMI0000485, } \\
\text { RMI0000481, RMI0000526, RMI0000487, } \\
\text { RMI0000525, RMI0000491, RMI0000488, } \\
\text { RMI0000476, RMI0000498 }\end{array}$ \\
\hline August & $\begin{array}{l}\text { RMI0000526, RMI0000491, RMI0000525, } \\
\text { RMI0000484, RMI0000476, RMI0000478, } \\
\text { RMI0000488, RMI0000487, RMI0000485, } \\
\text { RMI0000481 }\end{array}$ \\
\hline September & $\begin{array}{l}\text { RMI0000476, RMI0000478, RMI0000487, } \\
\text { RMI0000498, RMI0000525, RMI0000526 }\end{array}$ \\
\hline October & $\begin{array}{l}\text { RMI0000498, RMI0000491, RMI0000525, } \\
\text { RMI0000488, RMI0000526, RMI0000487, } \\
\text { RMI0000484, RMI0000478 }\end{array}$ \\
\hline November & RMI0000481, RMI0000476 \\
\hline
\end{tabular}

Source: [19]

\section{High-Frequency Patterns Calculations}

\section{Calculation of 1 itemset}

To calculate 1 itemset or $\mathrm{C} 1$ with a minimum support value of $90 \%$ can be obtained by the following formula:

Support $(A)=\frac{\sum \text { Transactions contains } A}{\sum \text { Transactions }} \times 100 \%$
The following Table 3 contains the candidate of 1 item sets:

Table 3. List of 1 itemset candidate

\begin{tabular}{lll}
\hline Item Set & QTY & Support \\
\hline RMI0000086 & 4 & $36 \%$ \\
\hline RMI0000178 & 3 & $27 \%$ \\
\hline RMI0000187 & 3 & $27 \%$ \\
\hline RMI0000476 & 10 & $91 \%$ \\
\hline RMI0000478 & 10 & $91 \%$ \\
\hline RMI0000481 & 9 & $82 \%$ \\
\hline RMI0000484 & 9 & $82 \%$ \\
\hline RMI0000485 & 8 & $73 \%$ \\
\hline RMI0000487 & 10 & $91 \%$ \\
\hline RMI00000488 & 9 & $82 \%$ \\
\hline RMI0000498 & 9 & $82 \%$ \\
\hline RMI0000525 & 9 & $82 \%$ \\
\hline RMI0000526 & 10 & $91 \%$ \\
\hline Source:[19] & 7 & $64 \%$
\end{tabular}

With the minimum support value of $90 \%$, the data with the support value below $90 \%$ will be removed, looks like the following Table 4 :

Table 4 . List of 1 itemset with a minimum support value of $90 \%$

\begin{tabular}{lll}
\hline Item Set & QTY & Support \\
\hline RMI0000476 & 10 & $91 \%$ \\
\hline RMI0000478 & 10 & $91 \%$ \\
\hline RMI0000487 & 10 & $91 \%$ \\
\hline RMI0000525 & 10 & $91 \%$ \\
\hline
\end{tabular}

\section{Source:[19]}

Calculation of 2 itemset

To calculate 2 itemsets or $\mathrm{C} 2$ with a minimum support value of $90 \%$ can be obtained by the following formula:

Support $(A, B)=\frac{\sum \text { Transactions contains } A, B}{\sum \text { Transactions }} \times 100 \%$

The following Table 5 contains the candidate of 1 item sets:

Table 5. List of 2 itemset candidate

\begin{tabular}{lll}
\hline Item Set & QTY & Support \\
\hline RMI0000476, RMI0000478 & 9 & $82 \%$ \\
\hline RMI0000476, RMI0000487 & 9 & $82 \%$ \\
\hline RMI0000476, RMI0000525 & 9 & $82 \%$ \\
\hline RMI0000476, RMI0000481 & 9 & $82 \%$ \\
\hline RMI0000478, RMI0000487 & 10 & $91 \%$ \\
\hline RMI0000478, RMI0000525 & 10 & $91 \%$ \\
\hline RMI0000478, RMI0000484 & 9 & $82 \%$ \\
\hline RMI0000478, RMI0000488 & 9 & $82 \%$ \\
\hline RMI0000478, RMI0000491 & 9 & $82 \%$ \\
\hline RMI0000478, RMI0000498 & 9 & $82 \%$ \\
\hline RMI0000487, RMI0000525 & 10 & $91 \%$ \\
\hline RMI0000487, RMI0000484 & 9 & $82 \%$ \\
\hline RMI0000487, RMI0000488 & 9 & $82 \%$ \\
\hline RMI0000487, RMI0000491 & 9 & $82 \%$ \\
\hline RMI0000487, RMI0000498 & 9 & $82 \%$ \\
\hline RMI0000525, RMI0000484 & 9 & $82 \%$ \\
\hline RMI0000525, RMI0000488 & 9 & $82 \%$ \\
\hline RMI0000525, RMI0000491 & 9 & $82 \%$ \\
\hline RMI0000525, RMI0000498 & 9 & $82 \%$
\end{tabular}




\section{JITK (JURNAL ILMU PENGETAHUAN} DAN TEKNOLOGI KOMPUTER)
VOL. 6. NO. 2 FEBRUARY 2020

P-ISSN: 2685-8223 I E-ISSN: 2527-4864

DOI: 10.33480/jitk.v6i2.1909

\begin{tabular}{lll}
\hline RMI0000484, RMI0000488 & 9 & $82 \%$ \\
\hline RMI0000484, RMI0000491 & 9 & $82 \%$ \\
\hline RMI0000488, RMI0000491 & 9 & $82 \%$
\end{tabular}

Source:[19]

With the minimum support value of $90 \%$, the data with the support value below $90 \%$ will be removed, looks like the following Table 6:

Table 6. List of 2 itemsets with a minimum support value of $90 \%$

\begin{tabular}{|c|c|c|}
\hline Item Set & QTY & Support \\
\hline RMI0000478, RMI0000487 & 10 & $91 \%$ \\
\hline RMI0000478, RMI0000525 & 10 & $91 \%$ \\
\hline RMI0000487, RMI0000525 & 10 & $91 \%$ \\
\hline
\end{tabular}

Source: [19]

\section{Calculation of 3 itemset}

To calculate 3 itemsets or $\mathrm{C} 3$ with a minimum support value of $90 \%$ can be obtained by the following formula:

Support $(A, B, C)=$

$\frac{\sum \text { Transactions contains } A, B, C}{\sum \text { Transactions }} \times 100 \%$

The following Table 7 contains the candidate of 3 item sets:

Table 7. List of 3 itemset candidate

\begin{tabular}{lll}
\hline Item Set & QTY & Support \\
\hline $\begin{array}{l}\text { RMI0000476, RMI0000478, } \\
\text { RMI0000487 }\end{array}$ & 9 & $82 \%$ \\
\hline $\begin{array}{l}\text { RMI0000476, RMI0000478, } \\
\text { RMI0000525 }\end{array}$ & 9 & $82 \%$ \\
\hline $\begin{array}{l}\text { RMI0000476, RMI0000487, } \\
\text { RMI0000525 }\end{array}$ & 9 & $82 \%$ \\
\hline $\begin{array}{l}\text { RMI0000478, RMI0000487, } \\
\text { RMI0000525 }\end{array}$ & 10 & $91 \%$ \\
\hline $\begin{array}{l}\text { RMI0000478, RMI0000487, } \\
\text { RMI0000484 }\end{array}$ & 9 & $82 \%$ \\
\hline $\begin{array}{l}\text { RMI0000478, RMI0000487, } \\
\text { RMI0000488 }\end{array}$ & 9 & $82 \%$ \\
\hline $\begin{array}{l}\text { RMI0000478, RMI0000487, } \\
\text { RMI0000491 }\end{array}$ & 9 & $82 \%$ \\
\hline $\begin{array}{l}\text { RMI0000478, RMI0000487, } \\
\text { RMI0000498 }\end{array}$ & 9 & $82 \%$ \\
\hline $\begin{array}{l}\text { RMI0000478, RMI0000525, } \\
\text { RMI0000484 }\end{array}$ & 9 & $82 \%$ \\
\hline $\begin{array}{l}\text { RMI0000478, RMI0000525, } \\
\text { RMI0000488 }\end{array}$ & 9 & $82 \%$ \\
\hline $\begin{array}{l}\text { RMI0000478, RMI0000525, } \\
\text { RMI0000491 }\end{array}$ & 9 & $82 \%$ \\
\hline $\begin{array}{l}\text { RMI0000478, RMI0000525, } \\
\text { RMI0000498 }\end{array}$ & 9 & $82 \%$ \\
\hline $\begin{array}{l}\text { RMI0000478, RMI0000484, } \\
\text { RMI0000488 }\end{array}$ & 9 & $82 \%$ \\
\hline $\begin{array}{l}\text { RMI0000478, RMI0000484, } \\
\text { RMI0000491 }\end{array}$ & 9 & $82 \%$ \\
\hline $\begin{array}{l}\text { RMI0000478, RMI0000488, } \\
\text { RMI0000491 }\end{array}$ & 9 & $82 \%$ \\
\hline $\begin{array}{l}\text { RMI0000487, RMI0000525, } \\
\text { RMI0000484 }\end{array}$ & 9 & $82 \%$ \\
\hline $\begin{array}{l}\text { RMI0000487, RMI0000525, } \\
\text { RMI0000488, RMI0000525, }\end{array}$ & 9 & $82 \%$ \\
\hline
\end{tabular}

\begin{tabular}{lll}
\hline Item Set & QTY & Support \\
\hline RMI0000491 & & \\
\hline $\begin{array}{l}\text { RMI0000487, RMI0000525, } \\
\text { RMI0000498 }\end{array}$ & 9 & $82 \%$ \\
\hline $\begin{array}{l}\text { RMI0000487, RMI0000484, } \\
\text { RMI0000488 }\end{array}$ & 9 & $82 \%$ \\
\hline $\begin{array}{l}\text { RMI0000487, RMI0000484, } \\
\text { RMI0000491 }\end{array}$ & 9 & $82 \%$ \\
\hline $\begin{array}{l}\text { RMI0000487, RMI0000488, } \\
\text { RMI0000491 }\end{array}$ & 9 & $82 \%$ \\
\hline
\end{tabular}

Source:[19]

With the minimum support value of $90 \%$, the data with the support value below $90 \%$ will be removed, looks like the following Table 8:

Table 8. List of 3 itemsets with a minimum support value of $90 \%$

\begin{tabular}{lll}
\hline Item Set & QTY & Support \\
\hline $\begin{array}{l}\text { RMI0000478, RMI0000487, } \\
\text { RMI0000525 }\end{array}$ & 10 & $91 \%$ \\
\hline
\end{tabular}

Source: [19]

\section{Calculation of Association Rules}

After calculating all the high frequent itemset patterns and get the data with the minimum requirement[20], then the next step is finding the associative rules that meet the minimum requirements for confidence by $100 \%$ by calculating 2 itemsets with the following formula:

Confidence $(B \mid A)=$

$\frac{\sum \text { Transactions Contains } A, B}{\sum \text { Transactions } A} \times 100 \%$

The following Table 9 contains the association candidate:

Table 9. Association rules candidate

\begin{tabular}{llll}
\hline Item Set & Support & QTY & Confidence \\
\hline $\begin{array}{l}\text { if buy RMI0000478 then } \\
\text { buy RMI0000498 }\end{array}$ & $82 \%$ & $9 / 9$ & $100 \%$ \\
\hline $\begin{array}{l}\text { if buy RMI0000478 then } \\
\text { buy RMI0000491 }\end{array}$ & $82 \%$ & $9 / 9$ & $100 \%$ \\
\hline $\begin{array}{l}\text { if buy RMI0000491 then } \\
\text { buy RMI0000484 }\end{array}$ & $82 \%$ & $9 / 9$ & $100 \%$ \\
\hline $\begin{array}{l}\text { if buy RMI0000525 then } \\
\text { buy RMI0000491 }\end{array}$ & $82 \%$ & $9 / 9$ & $100 \%$ \\
\hline $\begin{array}{l}\text { if buy RMI0000525 then } \\
\text { buy RMI0000484 }\end{array}$ & $82 \%$ & $9 / 9$ & $100 \%$ \\
\hline $\begin{array}{l}\text { if buy RMI0000488 then } \\
\text { buy RMI0000491 }\end{array}$ & $82 \%$ & $9 / 9$ & $100 \%$ \\
\hline $\begin{array}{l}\text { if buy RMI0000491 then } \\
\text { buy RMI0000488 }\end{array}$ & $82 \%$ & $9 / 9$ & $100 \%$ \\
\hline $\begin{array}{l}\text { if buy RMI0000488 then } \\
\text { buy RMI0000484 }\end{array}$ & $82 \%$ & $9 / 9$ & $100 \%$ \\
\hline $\begin{array}{l}\text { if buy RMI0000484 then } \\
\text { buy RMI0000488 }\end{array}$ & $82 \%$ & $9 / 9$ & $100 \%$ \\
\hline $\begin{array}{l}\text { if buy RMI0000525 then } \\
\text { buy RMI0000488 }\end{array}$ & $82 \%$ & $9 / 9$ & $100 \%$ \\
\hline $\begin{array}{l}\text { if buy RMI0000487 then } \\
\text { buy RMI0000491 }\end{array}$ & $82 \%$ & $9 / 9$ & $100 \%$ \\
\hline $\begin{array}{l}\text { if buy RMI0000487 then } \\
\text { buy RMI0000484 }\end{array}$ & $82 \%$ & $9 / 9$ & $100 \%$ \\
\hline \begin{tabular}{l} 
if buy RMI0000487 then \\
\hline
\end{tabular} & $91 \%$ & $10 / 10$ & $100 \%$ \\
\hline
\end{tabular}


VOL. 6. NO. 2 FEBRUARY 2020

P-ISSN: 2685-8223 | E-ISSN: 2527-4864

DOI: 10.33480 /jitk.v6i2.1909

\section{JITK (JURNAL ILMU PENGETAHUAN DAN TEKNOLOGI KOMPUTER)}

\begin{tabular}{|c|c|c|c|}
\hline Item Set & Support & QTY & Confidence \\
\hline \multicolumn{4}{|l|}{ buy RMI0000525 } \\
\hline $\begin{array}{l}\text { if buy RMI0000487 then } \\
\text { buy RMI0000488 }\end{array}$ & $82 \%$ & $9 / 9$ & $100 \%$ \\
\hline $\begin{array}{l}\text { if buy RMI0000476 then } \\
\text { buy RMI0000481 }\end{array}$ & $82 \%$ & $9 / 9$ & $100 \%$ \\
\hline $\begin{array}{l}\text { if buy RMI0000525 then } \\
\text { buy RMI0000487 }\end{array}$ & $91 \%$ & $10 / 10$ & $100 \%$ \\
\hline $\begin{array}{l}\text { if buy RMI0000484 then } \\
\text { buy RMI0000491 }\end{array}$ & $82 \%$ & $9 / 9$ & $100 \%$ \\
\hline $\begin{array}{l}\text { if buy RMI0000478 then } \\
\text { buy RMI0000525 }\end{array}$ & $91 \%$ & $10 / 10$ & $100 \%$ \\
\hline $\begin{array}{l}\text { if buy RMI0000487 then } \\
\text { buy RMI0000498 }\end{array}$ & $82 \%$ & $9 / 9$ & $100 \%$ \\
\hline $\begin{array}{l}\text { if buy RMI0000525 then } \\
\text { buy RMI0000498 }\end{array}$ & $82 \%$ & $9 / 9$ & $100 \%$ \\
\hline $\begin{array}{l}\text { if buy RMI0000487 then } \\
\text { buy RMI0000478 }\end{array}$ & $91 \%$ & $10 / 10$ & $100 \%$ \\
\hline $\begin{array}{l}\text { if buy RMI0000478 then } \\
\text { buy RMI0000487 }\end{array}$ & $91 \%$ & $10 / 10$ & $100 \%$ \\
\hline $\begin{array}{l}\text { if buy RMI0000525 then } \\
\text { buy RMI0000478 }\end{array}$ & $91 \%$ & $10 / 10$ & $100 \%$ \\
\hline $\begin{array}{l}\text { if buy RMI0000478 then } \\
\text { buy RMI0000488 }\end{array}$ & $82 \%$ & $9 / 9$ & $100 \%$ \\
\hline $\begin{array}{l}\text { if buy RMI0000478 then } \\
\text { buy RMI0000484 }\end{array}$ & $82 \%$ & $9 / 9$ & $100 \%$ \\
\hline
\end{tabular}

that below the minimum requirement will be eliminated, and then the final association rules that meet the minimum requirement can be seen by the following Table 10.

Table 10. List of final association rules with a minimum support value of $90 \%$ and a minimum confidence value of $100 \%$

\begin{tabular}{|c|c|c|c|c|c|}
\hline \multirow{2}{*}{\multicolumn{2}{|c|}{$\begin{array}{l}\text { Item Set } \\
\text { if buy RMI0000487 then } \\
\text { buy RMI0000478 }\end{array}$}} & \multicolumn{2}{|c|}{ Support } & QTY & Confidence \\
\hline & & \multicolumn{2}{|l|}{$91 \%$} & $10 / 10$ & $100 \%$ \\
\hline \multicolumn{2}{|c|}{$\begin{array}{l}\text { if buy RMI0000478 then } \\
\text { buy RMI0000487 }\end{array}$} & \multicolumn{2}{|l|}{$91 \%$} & $10 / 10$ & $100 \%$ \\
\hline \multicolumn{2}{|c|}{$\begin{array}{l}\text { if buy RMI0000525 then } \\
\text { buy RMI0000478 }\end{array}$} & \multicolumn{2}{|l|}{$91 \%$} & $10 / 10$ & $100 \%$ \\
\hline \multicolumn{2}{|c|}{$\begin{array}{l}\text { if buy RMI0000478 then } \\
\text { buy RMI0000525 }\end{array}$} & \multicolumn{2}{|l|}{$91 \%$} & $10 / 10$ & $100 \%$ \\
\hline \multicolumn{2}{|c|}{$\begin{array}{l}\text { if buy RMI0000525 then } \\
\text { buy RMI0000487 }\end{array}$} & \multicolumn{2}{|l|}{$91 \%$} & $10 / 10$ & $100 \%$ \\
\hline \multicolumn{2}{|c|}{$\begin{array}{l}\text { if buy RMI0000487 then } \\
\text { buy RMI0000525 }\end{array}$} & \multicolumn{2}{|l|}{$91 \%$} & $10 / 10$ & $100 \%$ \\
\hline \multicolumn{6}{|c|}{ Source: [19] } \\
\hline \multicolumn{6}{|c|}{$\begin{array}{l}\text { From Table } 10 \text { above, the data that can be analyzed } \\
\text { which combination of raw materials ink that } \\
\text { purchased by PT Penjalindo Nusantara } \\
\text { simultaneously can be seen in Figure } 1 \text { below: } \\
\text { Source: [19] }\end{array}$} \\
\hline & & & 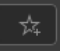 & 80 & $\square$ \\
\hline Support & Confidence & & Sup. & Conf. & Lift Ratio \\
\hline $90.91 \%$ & $10 / 10$ & $100 \%$ & 90.91 & & 1 \\
\hline $90.91 \%$ & $10 / 10$ & $100 \%$ & 90.91 & & 1 \\
\hline $90.91 \%$ & $10 / 10$ & $100 \%$ & 90.91 & & 1 \\
\hline $90.91 \%$ & $10 / 10$ & $100 \%$ & 90.91 & & 1 \\
\hline $90.91 \%$ & $10 / 10$ & $100 \%$ & 90.91 & & 1 \\
\hline $90.91 \%$ & $10 / 10$ & $100 \%$ & 90.91 & & 1 \\
\hline
\end{tabular}

A final association rule selected by the author is based on a combination of two item sets with the minimum support value of $90 \%$ with the minimum confidence of $100 \%$, the other association rules

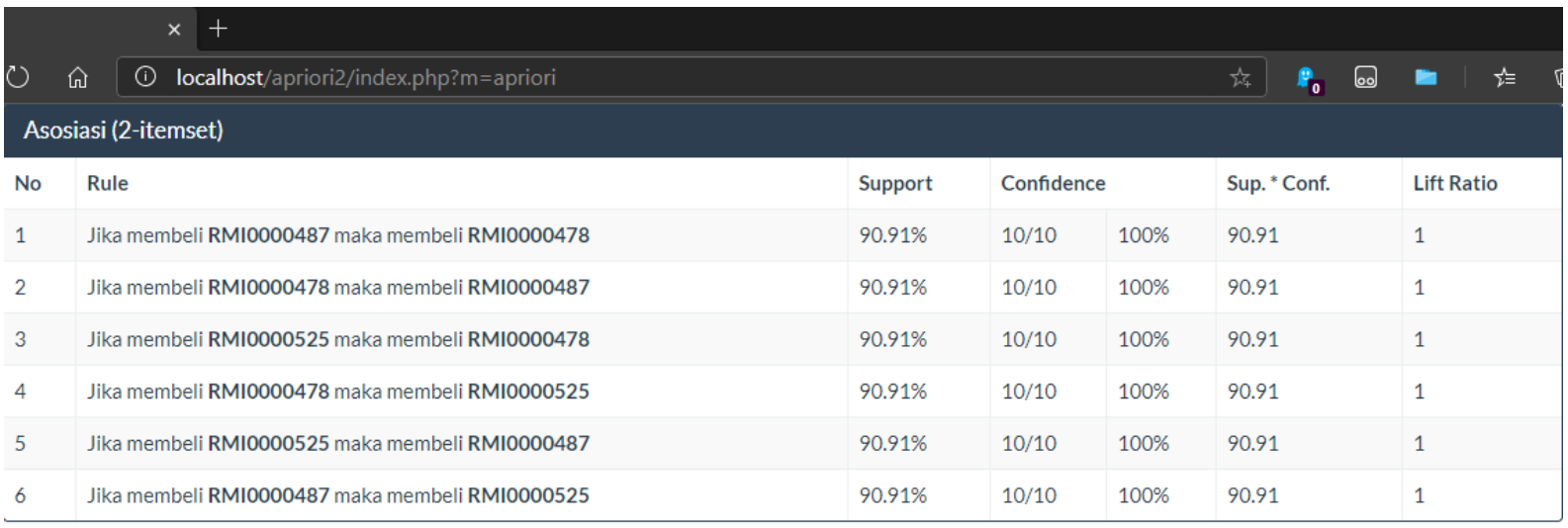

Figure 1. The Results of Final Association Rules Processed by Web Application

The results of the research based on the final association rules obtained from January 2020 to November 2020 there are 3 types of raw materials that are often purchased at the same time so that these results can be used as a reference for production material procurement officers or material planners in procuring raw material stock items and increase the effectiveness of raw material planning strategy.

\section{CONCLUSION}

The results of research by processed with the Apriori algorithm using the web-based application can solve the problems of raw material planning with the raw material purchase patterns that have a high percentage. The percentage of purchasing with the raw material PP_LNA 723 YELLOW @180 KG_HII and the raw material PU_LAMIC F 716 RED @180 KG_HII is $90 \%$ of support value and the percentage of confidence is $100 \%$. The percentage of purchasing with the raw material PU_LAMIC F 716 RED @180 KG_HII and the raw material PP_LNA 723 YELLOW @180 KG_HII is 90\% of support value and the percentage of confidence is 
$100 \%$. The percentage of purchasing with the raw material PP_LNA 795 BLACK @15 KG (PJ)_HII and the raw material PU_LAMIC F 716 RED @180 KG_HII is $90 \%$ of support value and the percentage of confidence is $100 \%$. The percentage of purchasing with the raw material PU_LAMIC F 716 RED @180 KG_HII and the raw material PP_LNA 795 BLACK @15 KG (PJ)_HII is 90\% of support value and the percentage of confidence is $100 \%$. The percentage of purchasing with the raw material PP_LNA 795 BLACK @15 KG (PJ)_HII and the raw material PP_LNA 723 YELLOW @180 KG_HII is $90 \%$ of support value and the percentage of confidence is $100 \%$. The percentage of purchasing with the raw material PP_LNA 723 YELLOW @180 KG_HII and the raw material PP_LNA 795 BLACK @15 KG (PJ)_HII is 90\% of support value and the percentage of confidence is $100 \%$.

\section{REFERENCE}

[1] K. Hidayat, J. Efendi, and R. Faridz, "Analisis Pengendalian Persediaan Bahan Baku Kerupuk Mentah Potato Dan Kentang Keriting Menggunakan Metode Economic Order Quantity (EOQ)," Performa Media Ilm. Tek. Ind., vol. 18, no. 2, pp. 125-134, 2020.

[2] N. Wahyu and E. P. Ningrum, "Penerapan Pengendalian Internal Melalui Pengelolaan Persediaan Bahan Baku (Studi Kasus Pada CV. Cipta Gemilang Karya Mandiri)," CAKRAWALA, vol. 1, no. 1, 2018.

[3] F. Sulaiman and Nanda, "PENGENDALIAN PERSEDIAAN BAHAN BAKU DENGAN MENGGUNAKAN METODE EOQ PADA UD. ADI MABEL," TEKNOVASI, vol. 2, no. 1, pp. 1-11, 2015.

[4] T. Pujadi, "Model Pemesanan Bahan Baku menggunakan Peramalan Time Series dengan CB Predictor," ComTech Comput. Math. Eng. Appl., vol. 5, no. 2, pp. 954-962, 2014.

[5] N. Apriyani and A. Muhsin, "Analisis Pengendalian Persediaan Bahan Baku Dengan Metode Economic Order Quantity Dan Kanban Pada Pt Adyawinsa Stamping Industries," Opsi, vol. 10, no. 2, p. 128, 2017.

[6] P. B. I. S. Putra, N. P. S. M. Suryani, and S. Aryani, "Analysis of Apriori Algorithm on Sales Transactions to Arrange Placement of Goods on Minimarket," IJEET Int. J. Eng. Emerg. Technol., vol. 3, no. 1, pp. 13-17, 2018.

[7] Munarwan, A. Sinaga, and U. Nugraha, "Implementation of Apriori Algorithm for Determining Purchase Patterns in One
Transaction," Int. J. Eng. Technol., vol. 7, no. 4.33, pp. 204-207, 2018.

[8] D. S. Wijaya and D. Fitrianah, "Data Mining Analysis with Association Rules Method to Determine the Result of Fish Catch using FP-Growth Algorithm," Int. J. Comput. Appl., vol. 181, pp. 7-15, 2018.

[9] Y. Nawawi and I. Suharjo, "Implementasi Data Mining Menentukan Rekomendasi Penempatan Buku Berdasarkan Pola Peminjaman Dengan Menggunakan Association Rule," J. Multimed. Artif. Intell., vol. 4, no. 1, 2020.

[10] A. Junaidi, "Implementasi Algoritma Apriori dan FP-Growth Untuk Menentukan Persediaan Barang," J. SISFOKOM, vol. 8, no. $1,2019$.

[11] D. A. O. Turang and S. R. Astari, "SISTEM MANAJEMEN INVENTORY MENGGUNAKAN ALGORITMA DIFFERENTIAL EVOLUTION," Semin. Nas. Inform. 2018 (semnasIF 2018), 2018.

[12] P. H. Simbolon, "Implementasi Data Mining Pada Sistem Persediaan Barang Menggunakan Algoritma Apriori ( Studi Kasus : Srikandi Cash Credit Elektronic dan Furniture )," J. Ris. Komput., vol. 6, no. 4, pp. 401-406, 2019.

[13] G. A. Syaripudin and E. Faizal, "Implementasi Algoritma Apriori Dalam Menentukan Persediaan Obat," JIKO Uurnal Inform. dan Komputer), vol. 2, no. 1, 2017.

[14] S. Wahyuni, Suherman, and L. P. Harahap, "Implementasi Data Mining dalam Memprediksi Stok Barang Menggunakan Algoritma Apriori," J. Tek. DAN Inform., vol. 5, no. ISSN 2089-5490, 2018.

[15] F. Kurniawan, B. Umayah, J. Hammad, S. M. S. Nugroho, and M. Hariadi, "Market Basket Analysis to Identify Customer Behaviors by Way of Transaction Data," Knowl. Eng. Data Sci., vol. 1, no. 1, pp. 20-25, 2018.

[16] M. T. Permatasari and H. D. Purnomo, "Penerapan Algoritma Apriori Untuk Mengetahui Pola Penempatan Buku dan Rekomendasi Persediaan Buku di Perpustakaan Daerah Kota Salatiga," 2019.

[17] R. Wahyuning, A. M. Kom, L. S. M. Kom, H. Wijaya, and T. Informatika, "Penerapan Association Rule Pada Data Persediaan Bahan Baku Di Pro Ab Chicken Jambi," Fortech, vol. 1, no. 1, pp. 43-48, 2017.

[18] L. Kurniawati, A. E. Kusuma, and B. Dewansyah, "Implementasi Algoritma Apriori Untuk Menentukan Persediaan Spare Part Compressor," Comput. Eng. Sci. Syst. J., vol. 4, no. 1, p. 6, 2019.

[19] D. R. Prastyo, "Implementasi Algoritma 
Apriori Untuk Menentukan Pola Pembelian Bahan Baku di PT Penjalindo Nusantara," Jakarta, 2020.

[20] S. Anggraeni, M. A. Iha, W. Erawati, and S. Khairunnas, "Analysis of Sales by Using Apriori and FP-Growth at PT. Panca Putra Solusindo," Ris. dan E-Jurnal Manaj. Inform. Komput., vol. 3, no. 2, pp. 41-46, Mar. 2019. 